\title{
Manic Episode Following Deep Brain Stimulation of the Subthalamic Nucleus for Parkinson's Disease: A Case Report
}

\author{
Parkinson Hastalığında Subtalamik Nükleusun Derin Beyin \\ Stimülasyonu Sonrası Gelişen Manik Atak: Bir Olgu Sunumu
}

\author{
Tugce TOKER UGURLU ${ }^{1}$, Goksemin ACAR $^{2}$, Filiz KARADAG ${ }^{1}$, Feridun ACAR ${ }^{3}$ \\ ${ }_{1}^{1}$ Pamukkale University, Faculty of Medicine, Department of Psychiatry, Denizli, Turkey \\ ${ }^{2}$ Pamukkale University, Faculty of Medicine, Department of Neurology, Denizli, Turkey \\ ${ }^{3}$ Pamukkale University, Faculty of Medicine, Department of Neurosurgery, Denizli, Turkey
}

Corresponding Author: Tugce TOKER UGURLU / E-mail: tugtoker@gmail.com

\begin{abstract}
AIM: Deep brain stimulation (DBS) of the subthalamic nucleus (STN) is an established therapy for patients with Parkinson's disease (PD) associated with motor complications of long term L-dopa treatment.

MATERIAL and METHODS: Here we report two cases with DBS- induced manic episode, focusing on the functional and anatomic correlates of psychiatric adverse effects of STN stimulation.

RESULTS: We present two cases of PD with motor complications due to long term L-dopa treatment that developed their first episodes of mania with psychotic symptoms after bilateral STN-DBS implantation. DBS-induced psychiatric adverse effects may be attributable either to limbic connections and STN-specific oscillations or stimulation of the medial forebrain bundle.
\end{abstract}

KEYWORDS: Deep brain stimulation, Subthalamic nucleus, Mania, Parkinson's disease

öz

AMAÇ: Subtalamik nükleusun (STN) derin beyin stimülasyonu (DBS), uzun süreli L-dopa tedavisinin motor komplikasyonlarının geliştiği Parkinson Hastalığı (PH)'nda uygulanan bir tedavidir.

YÖNTEM ve GEREÇLER: Bu yazıda, STN stimülasyonunun psikiyatrik yan etkilerinin anatomik ve fonksiyonel bağlantıları üzerinde durularak, DBS sonrasında manik atak gelişen iki olgunun sunulması amaçlandı.

BULGULAR: Uzun süreli L-dopa tedavisine bağlı motor komplikasyonları olan ve STN-DBS uygulaması sonrası ilk psikotik belirtili manik atağı ortaya çıkan iki PD olgusunu sunduk. DBS ilişkili psikiyatrik yan etkiler ya limbik bağlantılara ve STN spesifik osilasyonlara ya da medyal ön beyin demetinin uyarılmasına bağlı olabilir.

ANAHTAR SÖZCÜKLER: Derin beyin stimülasyonu, Subtalamik nükleus, Mani, Parkinson hastalığı

\section{INTRODUCTION}

Parkinson's disease $(\mathrm{PD})$ is a progressive neurodegenerative disorder characterized by bradykinesia, resting tremor, rigidity and postural instability. Psychiatric symptoms can ocur in $61 \%$ of the patients either due to disease itself or medication adverse effects. In $30-40 \%$ of patients have depression and $30 \%$ have psychosis related to seratonergic and dopaminergic deficits in the mesolimbic and mesocortical Networks (20).

Over the last two decades surgical therapies became the second most important therapeutic application after L-dopa and dopamine agonists. Deep brain stimulation (DBS) of the subthalamic nucleus (STN) is one of the major targets for relieving severe tremor or motor complications of long term L-dopa therapy. High frequency stimulation of STN in severely disabled patients due to motor complications of dopaminergic treatment is associated with a marked improvement in the quality of life measures $(6,1)$. However, it has been reported that a wide spectrum of behavioral change and psychiatric adverse effects occur as high as $41 \%$ for cognitive deficits, $8 \%$ for depression, $4 \%$ for acute hypomania $(16,17)$.

Here we report two cases of patients who developed manic episodes in the early postoperative period following bilateral STN-DBS.

\section{CASE 1}

A 56-year-old woman with a 12 year history of PD had been treated with L-dopa. Although relieving her bilateral resting tremor, bradykinesia, the best management of her treatment did not succeed in decreasing the motor complications of the 
dopaminergic therapy. She had bilateral rigidity, resting tremor predominating on the left side of her body. Unified Parkinson's Disease Rating Scale (UPDRS) motor score was 33 "off medication" and reduced to 12 "on medication" accompanied by severe dyskinesia in four limbs. Her psychiatric evaluation revealed exacerbating and remitting depressive episodes that were responsive to $20 \mathrm{mg} / \mathrm{d}$ citalopram treatment. During the last month she reported increased depressive mood, insomnia and anhedonia. Hamilton Depression Scale score was 18 and $10 \mathrm{mg} / \mathrm{d}$ escitalopram was recommended in the postoperative period.

Quadripolar electrodes (Medtronic 37601 activa PC) were implanted bilaterally with stereotactic methods as described elsewhere (7). On postoperative day 7 (5th day of escitalopram treatment) she developed inappropriate behaviors such as running in the hall, singing out loud and undressing. Her postoperative psychiatric evaluation revealed increased and rapid speech, racing thoughts, disjointed thinking, euphoria, grandiosity, persecutive hallucinations, religious activities, increased libido, psychomotor activity, insomnia, deterioration of reality assessment and judgment and lack of insight. Young Mania Scoring Scale (YMSS) was 38 and diagnosed as manic episode with psychotic symptoms, eventually put on $10 \mathrm{mg} / \mathrm{d}$ olanzapine and escitalopram was ceased. In follow-up psychiatric evaluation after one month she had none of the previous manic symptoms and YMSS was 0. Olanzapine was tapered down and ceased. In her neurological examination UPDRS score was 10 "on stimulation" and "on medication" and severe dyskinesias disappeared. After her second follow-up visit she was put on $10 \mathrm{mg} / \mathrm{d}$ escitalopram because of anxiety, decreased libido and increased appetite. Ten months after STN-DBS implantation she was euthymic and had no manic symptoms.

\section{CASE 2}

A 57-year-old man with a 10-year history of unilateral tremor and bradykinesia was admitted to neurosurgery clinic for STNDBS implantation because of severe motor complications of L-dopa treatment. His neurological examination revealed bilateral resting tremor and bradykinesia predominating on the left side of his body. Motor score of UPDRS was 30 "off" medication. In his preoperative psychiatric evaluation there was no active psychopathology. Bilateral STN-DBS implantation was carried out as described above. In the third postoperative day he was re-evaluated because of elevated mood, increased speech, hyperactivity and spending sprees. His psychiatric evaluation revealed increased and rapid speech, racing thoughts, disjointed thinking and euphoria. YMSS was 26 and was put on $1 \mathrm{mg} / \mathrm{d}$ haloperidol, tapered to $2 \mathrm{mg} / \mathrm{d}$. During the following weeks his manic symptoms subsided and YMSS was 0 . Motor scores of UPDRS reduced to 7 "on stimulation" and "on medication" and peak-dose dyskinesias disappeared. During his follow-up visit for increased tremor and bradykinesia stimulation intensity was increased. Approximately 24 hours following the new parameter settings (bipolar $3.5 \mathrm{~V} 90 \mu \mathrm{sec}, 180 \mathrm{~Hz}$ ) he developed an abrupt manic reaction which gradually subsided in 3 days after switching to more dorsal electrode contacts.

\section{DISCUSSION}

We present two cases of PD with motor complications due to long term L-dopa treatment that developed their first episodes of mania with psychotic symptoms after bilateral STN-DBS implantation. Several authors have reported a wide spectrum of psychiatric alterations after STN-DBS, such as depression, manic episode and anxiety $(19,18,13,8,2,15$, 21). A decompensation of preexisting psychiatric disorders such as depression and anxiety disorders can be induced by STN-DBS. Krack and colleagues reported a case with mirthful laughter when stimulated with supramaximal parameters (9). Besides, hypomania/mania has also been reported by many authors $(19,18,13,8)$. Romito and associates described 2 patients with transient mania associated with hypersexuality appeared in several days after initiation of STN stimulation. In these cases stimulation arrest did not acutely influence manic symptoms (14). Our first case STN-DBS related mania appeared on postoperative day 7 and continued for 1 month and gradually subsided with medical treatment. We think that her underlying affective disorder may be a predisposing factor for her DBS induced mania. In another report a reversible manic behavior was related to stimulation of contacts misplaced to caudal STN in the midbrain level and the manic behavior disappeared after stimulation of a different contact located in the level of STN. Thus, the authors concluded that manic disorders might be caused by affection of structures in the ventral midbrain (10). Similarly, Raucher-Chene and colleagues (13) reported a patient with manic episodes due to STN-DBS who responded to the change in stimulation target. They suggested that medial part of the STN play a key role in the occurrence of manic symptoms. However, Herzog and associates (8) suggested that stimulation of the STN, but not the adjacent structures resulted in manic psychosis. In their report bilateral monopolar stimulation of STN resulted in hypomanic state which progressed to a manic episode with psychotic symptoms in 3 weeks. Stimulation arrest was intolerable because of immediate worsening of motor symptoms. The patient has been put on $150 \mathrm{mg} / \mathrm{d}$ clozapine which alleviated the psychotic symptoms. However, mixed features both with mania and depression at the same time led to the diagnosis of organic bipolar disorder which is attributed to stimulation of STN but not adjacent structures. There is a similarity between hypomania in bipolar disorder and DBS-induced hypomania. In DBS-induced hypomania patients often report that they feel possessed $(8,14)$. They are overactive without signs of exhaustion. They engage in individually specific but overlapping risk-taking activities such as hypersexuality, gambling and money spending. Many authors had suggestions on the anatomic and functional correlates of these symptoms with STN stimulation. In our second case, manic symptoms appeared on postoperative day 3 and continued for a few weeks. He also reported hyperactivity and spending like in cases previously reported $(8,14)$. We think that, the stimulation of caudal STN has an 
important influence on the appearance of manic symptoms, because an abrupt manic reaction occurred which gradually subsided in 3 days after switching to more dorsal electrode contacts.

The STN has an anatomically central position within the basal ganglia-thalamocortical associative and limbic circuits. Despite the fact that it is a very small structure, it is a major player in the input and output of the basal ganglia motor circuitry. The involvement of the STN in motor function regulation is obvious and its stimulation has an immediate and robust clinical effect on PD. This may be explained by its role within the basal gangliathalamocortical circuitry. Besides its control on motor activity, the STN is involved in the processing of certain cognitive and executive functions and modulating motivation $(3,4)$. These features may be related to dopamine dysregulation syndrome, impulse control disorders and punding in PD (11). However, the involvement of STN in non-motor function is less robust and usually temporary. Therefore STN may be an indirect modulator of non-motor functions. Most authors postulate that STN induced psychiatric adverse effects are a result of diffusion of current into the inferior and medial STN, influencing its limbic subnucleus and its associated circuitry $(17,10)$. Recent functional neurosurgery has provided the opportunity to record directly from the human basal ganglia, most commonly in patients with PD undergoing DBS electrode implantation. The studies focusing on single unit recordings and local field potentials recorded intraoperatively via microelectrodes demonstrated that specific oscillations in the STN are involved in decisional processes, cognitive functions, emotion control and conflict that could explain the post-DBS occurrence of behavioral disturbances (12). However in a single report acute hypomania induced during STN-DBS attributed to activation of medial forebrain bundle which is a structure of the reward circuitry and a key structure of mesolimbic-dopamine system that is related to affective disorders, drug addiction and learning (5).

In conclusion, DBS-induced psychiatric adverse effects may be attributable either to limbic connections and STN-specific oscillations or stimulation of the medial forebrain bundle. The exact role of the STN and the basal ganglia in non-motor functions remains an important and interesting challenge for future research.

\section{REFERENCES}

1. Altuğ F, Acar F, Acar G, Cavlak U: The influence of subthalamic nucleus deep brain stimulation on physical, emotional, cognitive functions and daily living activities in patients with Parkinson's disease. Turk Neurosurg 21: 140-146, 2011

2. Appleby BS, Duggan PS, Regenberg A, Rabins PV: Psychiatric and neuropsychiatric adverse events associated with deep brain stimulation: A meta-analysis of ten years' experience. Mov Disord 22:1722-1728, 2007

3. Baunez C, Amalric M, Robbins TW: Enhanced food related motivation after bilateral lesions of the subthalamic nucleus. J Neurosci 22: 562-568, 2002
4. Baunez C, Dias C, Cador M, Amalric M: The subthalamic nucleus exerts opposite control on cocaine and "natural" rewards. Nat Neurosci 8: 484-489, 2005

5. Coenen VA, Honey CR, Hurwitz T, Rahman AA, McMaster $J$, Bürgel $U$, Madler B: Medial forebrain bundle stimulation as a pathophysiological mechanism for hypomania in subthalamic nucleus deep brain stimulation for Parkinson's Disease. Neurosurgery 64: 1106-1115, 2009

6. Deuschl G, Schade-Brittinger C, Krack P, Volkmann J, Schäfer $H$, Bötzel K, Daniels $C$, Deutschländer A, Dillmann U, Eisner W, Gruber D, Hamel W, Herzog J, Hilker R, Klebe S, Kloss M, Koy J, Krause M, Kupsch A, Lorenz D, Lorenzl S, Mehdorn HM, Moringlane JR, Oertel W, Pinsker MO, Reichmann H, Reuss A, Schneider GH, Schnitzler A, Steude U, Sturm V, Timmermann L, Tronnier V, Trottenberg T, Wojtecki L, Wolf E, Poewe W, Voges J, German Parkinson Study Group, Neurostimulation Section: A randomized trial of deep-brain stimulation for Parkinson's disease. N Engl J Med 355: 896-908, 2006

7. Goetz CG, Koller WC, Poewe W, Rascol O, Sampaio C: Management of Parkinson's disease: An evidence-based review. Mov Disord 17: 1-166, 2002

8. Herzog J, Reiff J, Krack P, Witt K, Schrader B, Müller D, Deuschl G: Manic episode with psychotic symptoms induced by subthalamic nucleus stimulation in a patient with parkinson's disease. Mov Disord 18: 1382-1384, 2003

9. Krack P, Kumar R, Ardouin C, Dowsey PL, McVicker JM, Benabid $A L$, Pollak P: Mirthful laughter induced by subthalamic nucleus stimulation. Mov Disord 16: 867-875, 2001

10. Kulisevsky J, Berthier ML, Gironell A, Pascual-Sedano B, Molet J, Pares P: Mania following deep brain stimulation for parkinson's disease. Neurology 59: 1421-1424, 2002

11. Lim SY, O'Sullivan SS, Kotschet K, Gallagher DA, Lacey C, Lawrence AD, Lees AJ, O'Sullivan DJ, Peppard RF, Rodrigues JP, Schrag A, Silberstein P, Tisch S, Evans AH: Dopamine dysregulation syndrome, impulse control disorders and punding after deep brain stimulation surgery for Parkinson's disease. J Clin Neurosci 16: 1148-1152, 2009

12. Marceglia S, Fumagalli M, Priori A: What neurophysiological recordings tell us about cognitive and behavioral functions of the human subthalamic nucleus. Expert Rev Neurother 11: 139-149, 2011

13. Raucher-Chene $D$, Charrel $C L$, Maindreville $A D$, Limosin F: Manic episode with psychotic symptoms in a patient with Parkinson's disease treated by subthalamic nucleus stimulation: Improvement on switching the target. J Neurol Sci 273: 116-117, 2008

14. Romito LM, Raja M, Daniele A, Contarino MF, Bentivoglio AR, Barbier A, Scerrati M, Albanese A: Transient mania with hypersexuality after surgery for high frequency stimulation of the subthalamic nucleus in Parkinson's disease. Mov Disord 17: 1371-1374, 2002

15. Soulas T, Gurruchaga JM, Palfi S, Cesaro P, Nguyen JP, Fenelon G: Attempted and completed suicides after subthalamic nucleus stimulation for Parkinson's disease. J Neurol Neurosurg Psychiatry 79: 952-954, 2008 
16. Temel Y, Kessels A, Tan S, Topdag A, Boon P, Visser-Vandewalle V: Behavioural changes after bilateral subthalamic stimulation in advanced Parkinson disease: A systematic review. Parkinsonism Relat Disord 12: 265-272, 2006

17. Tsai ST, Lin SH, Lin SZ, Chen JY, Lee CW, Chen SY: Neuropsychological effects after chronic subthalamic stimulation and the topography of the nucleus in Parkinson's disease. Neurosurgery 61: 1024-1030, 2007

18. Ulla M, Thobois S, Lemaire JJ, Schmitt A, Derost P, Broussolle E, Llorca PM, Durif F: Manic behaviour induced by deep-brain stimulation in Parkinson's disease: Evidence of substantia nigra implication? J Neurol Neurosurg Psychiatry 77: 1363-1366, 2006
19. Ulla M, Thobois S, Llorca PM, Derost $P$, Lemaire JJ, ChereauBoudet I, de Chazeron I, Schmitt A, Ballanger B, Broussolle E, Durif F: Contact dependent reproducible hypomania induced by deep brain stimulation in Parkinson's disease: Clinical, anatomical and functional imaging study. J Neurol Neurosurg Psychiatry 82: 607-614, 2011

20. Virit O, Altındağ A, Akçalı A, Bulut $M$, Savaş HA: Effective treatment with electroconvulsive therapy of three cases with Parkinson disease, psychosis and depression. Anatolian Journal of Psychiatry 11: 79-82, 2010

21. Voon V, Krack P, Lang AE, Lozano AM, Dujardin $K$, Schüpbach M, D'Ambrosia J, Thobois S, Tamma F, Herzog J, Speelman JD, Samanta J, Kubu C, Rossignol H, Poon YY, Saint-Cyr JA, Ardouin C, Moro E: A multicentre study on suicide outcomes following subthalamic stimulation for Parkinson's disease. Brain 131: 2720-2728, 2008 